\title{
Desconstruindo o preconceito racial no ensino médio: o uso da educomunicação no ensino de biologia no IFPA - Belém
}

\author{
Luiz Cláudio dos Anjos Fernandes* \\ Wilkelly Alves de Lima**
}

Resumo: Este artigo objetiva apresentar, a partir do ensino crítico de Biologia, as possibilidades de desconstrução do preconceito racial, tendo como eixo condutor reflexões, provocadas pela teoria Eva Mitocondrial e, como suporte pedagógico, a Educomunicação, usada por professores de Biologia do IFPA - Campus Belém, sujeitos da pesquisa. Quando aliados, esses dois elementos possibilitam uma educação voltada para as relações etnicorraciais. O estudo consistiu em uma pesquisa qualitativa, do tipo Estudo de Caso, cujos dados foram coletados mediante entrevistas semiestruturadas e questionários mistos. Os resultados obtidos revelaram que o campo da Biologia é fundamental para a desconstrução de estereótipos, sendo a Genética uma das principais vertentes de esclarecimentos, e a teoria Eva Mitocondrial fundamental para a valorização dos povos e da cultura de origem africana e afrobrasileira.

Palavras-chave: Educomunicação, ensino de Biologia, preconceito racial.

\footnotetext{
* Bacharel em Comunicação Social-Jornalismo pela Faculdade de Estudos Avançados do Pará (Feapa). Membro do Grupo de Pesquisa para Incentivo e Promoção de Pesquisas no IFPA. Jornalista do jornal Voz de Nazaré. E-mail: luizclaudio.jornalismo@gmail.com

** Graduada em Biologia pelo Instituto Federal de Educação, Ciência e Tecnologia do Pará (IFPA)- Campus Belém. E-mail: wkalves@gmail.com
} 


\section{Introdução}

$\mathrm{O}$ número de educadores preocupados com os debates sobre a temática etnicorracial torna-se cada vez maior em função, principalmente, de políticas e práticas afirmativas. Esse debate vem contribuindo para a reflexão sobre o papel da escola enquanto espaço de afirmação de identidades. Tais ações defendem uma educação que respeite as especificidades da população negra (SILVA, 1998).

A escola, como instituição de ensino, tem por função ensinar valores indispensáveis à formação de um bom cidadão. Aprender a ser cidadão é comprometer-se com a vida da comunidade e do país, fazendo uso de atitudes respeitosas, responsáveis e que, dentre outros, combatam pensamentos preconceituosos, de modo a promover ideais de igualdade (BRASIL, 2007).

É por isso que muitos autores defendem a autonomia do aluno na construção do conhecimento: para que tenham posicionamento crítico e ajudem a promover a igualdade. Moran (2006), por exemplo, nos mostra que os alunos estão acostumados a receber informações prontas do professor. Desta maneira, não tomam a decisão de produzir algo eles próprios, sentem-se desconfortáveis quando estimulados pelo professor a tomarem suas próprias decisões com relação ao que produzir. Levamos em consideração, também, a afirmação de Gadotti (2005) de que "a escola precisa ser ousada, promover a autonomia do aluno, fazendo-o construir e reconstruir conhecimento".

Para Freire (1996), o professor deve saber utilizar o momento de dificuldade do aluno para incentivá-lo a raciocinar e formar seu conhecimento, direcionando-o de forma mais lúdica, sem cobranças ou indução, pois ocorre assim, uma interação mais estreita entre eles. Esse é um passo importante para ajudar o aluno a ter um posicionamento crítico e para contribuir com a diminuição das desigualdades sociais e raciais no Brasil, refletidas na educação e por ela reforçadas.

Mesmo com o crescente ritmo de industrialização e urbanização no Brasil, os critérios de seleção social de acordo com a tonalidade da pele ainda persistem, paralelamente às contínuas desigualdades sociais (CHAGAS, 2010). De acordo com o Plano Nacional de Implementação das Diretrizes Curriculares Nacionais para Educação das Relações Etnicorraciais e para o Ensino de História e Cultura Afrobrasileira e Africana (Brasil, 2003), a educação brasileira organiza-se por níveis e modalidades de ensino, expressos na Lei de Diretrizes e Bases da Educação.

Com o estudo, tivemos como foco apontar possibilidades do ensino de Biologia com o intuito de ajudar a desconstruir estereótipos, incluindo o preconceito racial, à luz de reflexões provocadas pela teoria Eva Mitocon- 
drial $^{1}$ e tendo como suporte pedagógico a Educomunicação ${ }^{2}$, voltada à educação para as relações etnicorraciais e usada por professores. Desta maneira, esta pesquisa estudou os docentes de Biologia do IFPA - Campus Belém, atuantes no $2^{\circ}$ ano do ensino médio, uma vez que, nessa série, a Genética (ciência dos genes) ganha destaque como disciplina.

Neste nível de ensino, os alunos estão aptos a compreender o processo de transmissão de características adquiridas por meio da hereditariedade, além da definição de DNA e genes, e a participação destes ao longo de gerações. Com isso, a teoria da Eva Mitocondrial pode ser utilizada como forte embasamento teórico para fazê-los repensar o imagético negro criado socialmente, a partir do preconceito e da discriminação racial.

A pesquisa ratificou a preocupação da Educomunicação com as diferentes abordagens e a utilização de mecanismos inovadores para o auxílio no processo de ensino-aprendizagem da Biologia 3 .

Com a problematização: “A Educomunicação é utilizada por professores de Biologia do IFPA-Campus Belém, como perspectiva de ensino aprendizagem e reflexão crítica acerca do preconceito racial, em turmas de $2^{\circ}$ ano do ensino médio?", sublinhamos o objetivo do estudo: Analisar o uso da Educomunicação por professores de Biologia do IFPA-Campus Belém, como perspectiva de ensino aprendizagem e reflexão crítica acerca do preconceito racial, em turmas de $2^{\circ}$ ano do ensino médio. Para tanto, buscamos averiguar se o professor de Biologia utiliza a Educomunicação; investigar a forma como o professor usa o recurso didático; e identificar na fala do professor as vantagens e desvantagens do uso da Educomunicação no ensino dessa disciplina voltada para a educação etnicorracial.

Ao nos depararmos com as condições e utilização dos recursos didáticos ${ }^{4}$, percebemos que há pouca eficiência no aproveitamento desses instrumentos. Alguns recursos como revistas, data shows, vídeos e livros, por serem elementos de motivação de aprendizagem, estimulam os alunos a terem

\footnotetext{
${ }^{1}$ Segundo a teoria Eva Mitocondrial, há um ancestral comum mais recente matrilinear de todos os seres humanos vivos na atualidade. O seu DNA mitocondrial teria sido passado de geração em geração e estaria agora presente em todas as pessoas. Todo o DNA mitocondrial, em todas as pessoas do mundo, seria derivado do DNA mitocondrial da Eva Mitocondrial. É a contraparte do Adão-Y, o ancestral comum mais recente patrilinear, embora tenham vivido em tempos diferentes. Em 1986, pesquisadores da Universidade da Califórnia concluíram que todos os humanos eram descendentes de uma única mulher que viveu na África há cerca de 200 mil anos, que denominaram de Eva Mitocondrial. Eles se basearam na análise do DNA retirado das mitocôndrias, que difere do DNA do núcleo da célula e é transmitido apenas pela linhagem feminina. Ele sofre mutações em rápidas proporções.

2 É tanto a prática quanto a teoria no que tange à relação entre Educação e Comunicação.

3 A ideia de construção dessa pesquisa se deu durante a realização da Especialização em Educação para as Relações Etnicorraciais (ERER), no IFPA - Campus Belém. Gradualmente, então, esse estudo em questão foi ganhando consistência e se solidificando. Com o auxílio da orientadora, houve acesso a um novo conhecimento: a Educomunicação. Foi necessário pesquisar sobre essa proposta educacional para compreender sua relação com o ensino e a aprendizagem na disciplina Biologia.
}

4 Recurso didático é todo material utilizado como auxílio no ensino de um conteúdo, como revista, data show, vídeo, livro, entre outros, devendo ser utilizado como um aliado em sala (SOUZA, 2007). 
maior interesse pelo assunto abordado e a participarem ativamente, facilitando, com isso, a fixação do conteúdo e dos conceitos (CASTOLDI, 2009). Assim, a pesquisa investigou também se o professor estaria preparado para utilizar recursos didáticos inovadores em sala de aula.

Tivemos como sujeitos informantes quatro docentes, das turmas de $2^{0}$ ano do ensino médio do IFPA, aqui identificados como: P1, P2, P3 e P4. A participação dos entrevistados na pesquisa como sujeitos investigados foi por aceitação ao convite do pesquisador e por adesão ao estudo.

Levando em consideração o uso da Educomunicação, percebemos que a promoção de trabalhos didáticos associados a diálogos e reflexões sobre temas como "o racismo e suas origens" permite que os alunos se tornem mais questionadores e que, após uma reflexão mais crítica, multipliquem essa reflexão, contribuindo para que haja uma modificação da sociedade e do padrão reprodutivista.

A pesquisa tratou de um estudo de caso, devido se concentrar no estudo de uma conjuntura particular. De acordo com Severino (2007), para ser um estudo de caso é necessário que o caso escolhido para a pesquisa seja significativo e representativo, de modo a ser apto a fundamentar uma generalização para situações análogas, possibilitando inferências.

A opção pelo trabalho com o contexto do Campus Belém, então, se deu pela compreensão de que, neste ambiente, a disciplina Educação para Relações Etnicorraciais já fazia parte do currículo das licenciaturas. Isso demonstra a relevância dada à temática na instituição, de modo a proporcionar discussões acerca dessa questão entre os discentes e os agentes da educação, em especial os docentes, os quais, por inferência, devem ser, em grande parte, detentores de informação e esclarecidos quanto à temática. Para efeito de apropriação da realidade local dos sujeitos investigados e com fins de qualificação e adaptação do projeto, foi feito um estudo exploratório inicial em campo.

A apropriação de conceitos, valores e atitudes que compõem o universo significativo dos sujeitos, especialmente dos professores entrevistados, tornou-se fundamental para a compreensão da sua relação com a Educomunicação e com demais propostas pedagógicas, neste caso, como o fenômeno estudado 5 .

A esse respeito, Minayo (2007) nos diz:

A pesquisa qualitativa responde a questões muito particulares. Ela se ocupa, nas Ciências Sociais, com nível de realidade que não pode ou não deveria ser quantificado. Ou seja, ela trabalha com o universo dos significados, dos motivos, das aspirações, das crenças, dos valores e das atitudes. Esse conjunto de fenômenos humanos é entendido aqui como parte da realida-

\footnotetext{
5 Do ponto de vista metodológico, este estudo configurou-se numa pesquisa qualitativa, pois se tratou de investigação da complexidade de significados sociais de sujeitos históricos inseridos na realidade social (MINAYO, 2007).
} 
de social, pois o ser humano se distingue não só por agir, mas por pensar sobre o que faz e por interpretar suas ações dentro e a partir da realidade vivida e partilhada com seus semelhantes (MINAYO, 2007, p. 21).

Considerando que na pesquisa trabalhamos com as falas significativas dos sujeitos investigados, o trato com a subjetividade enquanto constituinte das leituras sobre a Educomunicação permeou a dinâmica de apropriação dos dados coletados. Neste sentido, o papel do pesquisador não foi o de explicar e sim de compreender o fenômeno estudado, a partir da realidade em que se encontrava, relativizando seu olhar e validando como verdade os discursos dos sujeitos sobre suas próprias realidades. A abordagem qualitativa é considerada como sociologia compreensiva por Minayo (2007):

\begin{abstract}
Num embate direto com o positivismo, a Sociologia Compreensiva propõe a subjetividade como o fundamento do sentido da vida social e defende-a como constitutiva do social e inerente à construção da objetividade nas Ciências Sociais. Os autores compreensivistas não se preocupam em quantificar e em explicar, e sim em compreender: este é o verbo da pesquisa qualitativa. Compreender relações, valores, atitudes, crenças, hábitos e representações e a partir desse conjunto de fenômenos humanos gerados socialmente, compreender e interpretar a realidade (MINAYO, 2007, p. 23-24).
\end{abstract}

A etapa de coleta de dados foi processada de forma a acompanhar e observar os sujeitos investigados em suas práticas cotidianas, de acordo com suas permissões. Foram utilizadas para efeito de registro das falas, entrevistas semiestruturadas e aplicados questionários de forma a facilitar o surgimento de dados importantes para as respostas ao problema de pesquisa adotado. Consideramos diversas categorias para elaborar as perguntas: o histórico acadêmico do professor, envolvendo tempo de docência e sua formação, suas concepções acerca do ensino-aprendizagem e seu conhecimento sobre assuntos relacionados à questão etnicorracial e à Educomunicação.

$\mathrm{Na}$ fala dos entrevistados, foi possível perceber que a disciplina Biologia possui marcante relação com a compreensão do preconceito na sociedade brasileira. Assim, os dados coletados foram importantes também para a compreensão da importância da Biologia no processo de inclusão da Educomunicação, como um forte potencial auxiliador no processo de ensino-aprendizagem.

Este artigo é formado por quatro partes: a primeira aborda a relação existente entre o ensino da Biologia e o preconceito racial, envolvendo inicialmente as tendências pedagógicas que contribuíram para o avanço no ensino da Biologia. A segunda explica a teoria da Eva Mitocondrial, do que ela trata e de que forma ela pode contribuir com a desconstrução do imagético 
pejorativo do negro. A terceira contempla as contribuições da Educomunicação ao processo de ensino e aprendizagem de modo geral, e em especial à Biologia. A quarta e última destaca a análise dos dados, obtidos na pesquisa de campo realizada no Campus Belém, com os professores de Biologia da instituição.

\section{O Ensino da biologia e o preconceito racial}

Para a SECAD/MEC, a baixa reflexão na educação brasileira no que tange as relações no planejamento escolar impossibilita que relacionamentos interpessoais sejam respeitáveis e igualitários entre os que estão inseridos no ambiente estudantil (SANTOS, 2005). A Biologia, como ciência que estuda os seres vivos, suas constituições, a história evolutiva e as relações comportamentais entre indivíduos, pode ser uma grande aliada na desconstrução do imagético pejorativo do negro, o qual perpassa gerações.

Entre os assuntos pertinentes à disciplina, a Genética é um conteúdo especial porque abrange o estudo de cromossomos, as estruturas deles, o material genético humano (DNA), conceitos que envolvem genótipo e fenótipo, dentre outros, os quais somados são capazes de desmitificar uma das principais teorias que inferiorizam os negros, a qual Malavota (2011) chama de Corrente da Inferioridade Africana, em que os caracteriza como um grupo de seres selvagens, destituídos de inteligência e nascidos para serem subordinados.

Na disciplina de Biologia, os alunos podem ser instigados a questionar teorias discriminatórias, uma vez que, através do estudo científico, se esclarece que os indivíduos são iguais no sentido de não existir pessoas melhores ou piores que outras. As diferenças partem de uma pessoa para outra, pois cada ser humano possui sua personalidade, suas escolhas e atitudes, e um conjunto de características que o fazem único.

O racismo é um fenômeno ideológico que se consolida via preconceitos, discriminações e estereótipos, fortalecidos ao longo de gerações. A comunidade, o ambiente escolar e a sala de aula, assim como as relações interpessoais entre alunos, professores e direção da escola, são, dessa forma, alvos constantes de atitudes discriminatórias, perpassadas e reproduzidas a partir de um ideal histórico, em que o conceito de superioridade racial justificava a desigualdade e a imagem negativa sobre os povos negros (SANT'ANA, 
2001).

É necessário salientar que o surgimento da didática como ciência de investigação entre ensino e aprendizagem contribuiu para uma forte ligação entre as tendências pedagógicas do século XVII e o ensino de Biologia. Dessa forma, o surgimento da didática foi um grande avanço para a organização do ensino em seu bojo social, político e cultural, podendo a didática contribuir, inclusive, com um ensino originalmente voltado para a inclusão.

As principais tendências pedagógicas são divididas em dois grupos: abordagem liberal e progressista. O primeiro trata da Pedagogia Liberal: Tradicional, Renovada Progressista, Renovada Não-direta ou Escola Nova, e Tecnicista. Já a Pedagogia Progressista é subdividida em Libertadora, Libertária e crítico-social (LIBÂNEO, 2005). Cada tendência didática e pedagógica repercutiu diretamente no ensino de ciências. A história do ensino dessa disciplina proporciona a compreensão de como se apresenta o estudo de Biologia no contexto atual e as etapas que influenciaram mudanças significativas a respeito da importância dessa matéria na formação do indivíduo social.

Segundo Veiga (1978), após a década de 1960 e no período de repercussão tecnicista, a sociedade foi influenciada em prol da valorização do conhecimento científico. Desse modo, o ensino da ciência de modo geral adquiriu relevância objetiva. Portanto, a ciência objetiva se destaca em detrimento do ensino derivado da subjetividade.

Nesse período, o ensino da Biologia foi destacado por motivos que incluem o progresso científico, a constatação nacional e internacional da importância do ensino de ciências como fator de desenvolvimento e a Lei de Diretrizes e Bases da Educação Nacional (LDB) de 20 de dezembro de 1961, a qual descentralizou as decisões curriculares antes de responsabilidade da administração federal. Esse conjunto de acontecimentos favoreceu o ensino de Ciências:

A explosão do conhecimento biológico provocou uma transformação na tradicional divisão, botânica e zoologia, passando do estudo das diferenças para a análise de fenômenos comuns a todos os seres vivos. Essa análise, feita em todos os níveis de organização, da molécula à comunidade, teve como consequência incluir nos currículos escolares um novo e amplo espectro de assuntos, indo da ecologia e genética de populações até a genética molecular e a bioquímica (KRASILCHIK, 2004, p. 11).

Contudo, Borges (2007) afirma que mesmo com a valorização das disciplinas científicas em documentos oficiais (LDB/1971), o tempo de ensino disponibilizado ao ensino de Ciências (a Biologia no Ensino Fundamental é ministrada como Ciências) foi reduzido por motivo da alta força 
tecnicista presente no período, somado ao seu caráter profissionalizante. Além disso, apesar de as escolas precisarem seguir um ensino com base em conhecimentos atualizados e direcionados à aplicação prática do método científico, a disciplina Biologia em diversas escolas no Brasil continuou a ser descritiva, teórica e segmentada. Isso impossibilitou, durante muito tempo, um ensino voltado para os esclarecimentos relacionados às questões etnicorraciais. Orientações acerca do combate ao preconceito racial eram tímidas.

Apesar disso, Lévi-Strauss (1986, p. 21) já dizia que não era da competência de um etnólogo tentar dizer o que era, ou o que não era uma raça, pois os especialistas da antropologia física ${ }^{6}$, que a discutiam desde há dois séculos, jamais haviam chegado a um acordo e nada indicava que estivessem, naquela época, mais perto de se entenderem acerca de uma resposta àquela questão. Fracalanza e Fracalanza (1985, apud TEIXEIRA, 2008) analisaram o ensino da Biologia em meados da década de 1980 e apresentaram os seguintes comentários:

\begin{abstract}
- Está desatualizado, quer no que se relaciona à correção das informações, quer no que respeita à completa compreensão dos conceitos básicos envolvidos;

- Não reflete as diversas acepções sobre os fenômenos envolvidos, nem os paradigmas ou teorias explicativas a eles relacionadas;

- Não explicitam os contextos nos quais e para os quais os conhecimentos foram e são produzidos e difundem uma concepção errônea da ciência, de seus métodos de trabalho e das instituições científicas;

- Manifesta estreita relação com os conteúdos tradicionalmente solicitados nos exames de ingresso às escolas superiores e com os conteúdos do $3^{\mathbf{O}}$ grau;

- Envolvem modernizações sem relações estreitas com o contexto sociopolítico brasileiro (FRACALANZA e FRACALANZA, 1985, p. 42).
\end{abstract}

Diversas críticas foram discutidas quanto ao seu conteúdo e método utilizado pela disciplina em questão. Salles e Ferreira (2005) ratificam que, ao longo do séc. $\mathrm{XX}$, as críticas estão voltadas à seleção e organização dos conteúdos e da metodologia empregada, o que caracteriza o ensino como descritivo e memorístico.

No contexto escolar, o ensino da disciplina Biologia é considerado por Sant'ana (2010) como ultrapassado e desinteressante. A aplicação de novas tecnologias na sala de aula pode facilmente proporcionar um aprendizado

${ }^{6}$ A Antropologia Física é um subcampo da Antropologia e é fruto de uma interação interdisciplinar com a Biologia. Também é chamada de antropologia biológica ou bioantropologia e estuda os mecanismos de evolução biológica, herança genética, adaptabilidade e variabilidade humana, primatologia e o registro fóssil da evolução humana. 
eficaz, pois são levados em consideração a realidade e o meio em que o alunado está inserido. De modo geral, o ensino em sala de aula pode se tornar prazeroso quando o profissional da educação consegue estimular o interesse dos alunos pelo conteúdo ministrado. Isso pode ser facilmente desenvolvido à medida que o docente aplica recursos tecnológicos associados à realidade do público-alvo.

Assim como em outras disciplinas, o ensino da Biologia voltado para as questões etnicorraciais necessita se basear em materiais concretos, atividades práticas e recursos tecnológicos capazes de potencializar as aulas teóricas, de modo a aprimorar o conhecimento adquirido previamente pelo alunado. A televisão, os vídeos divulgados na internet, os documentários e as revistas são recursos midiáticos indispensáveis na explanação de conteúdos de Biologia, devido ser uma matéria que estimula bastante o visual (MAIA, 2008).

A tendência contemporânea no estudo da Biologia, estudada no trabalho de Borges (2007), mostrou levantamentos e análises de resumos publicados e destaca as principais categorias encontradas em sua pesquisa. Dentre elas, as mais estudadas, por ordem decrescente, são: Educação Ambiental; Ecologia; Botânica; Anatomia/Fisiologia; Zoologia; Saúde; Genética e Evolução, dentre outros assuntos e temas diversos.

No trabalho de Sales (2011), foram verificadas as tendências atuais no ensino de Biologia, para tanto foram analisados artigos publicados de 2006 a 2010 em cinco periódicos científicos nacionais. Por meio desse estudo, foi identificado que o nível escolar mais estudado é o nível fundamental e grande parte dos trabalhos não se restringe a uma subárea específica, a pesquisa é feita de forma mais genérica, o que, nesse caso, salienta a necessidade de direcionar mais as pesquisas.

Com isso, o ensino de Ciências no Brasil apresenta-se em processo de fortalecimento e concretização, o que se torna fundamental para atender a situação educacional da atualidade, de modo a exigir reflexão sobre os conteúdos (inclusive os que reforçam a questão etnicorracial) e os procedimentos metodológicos (BORGES, 2007). Nesse contexto, silenciar o racismo, o preconceito e a discriminação racial contribui para que essas questões sejam tratadas como desigualdades naturais e corriqueiras. O professor de Biologia, por meio de seus conhecimentos biológicos, é capaz de colaborar para uma sociedade mais igualitária e menos preconceituosa ao trabalhar questões etnicorraciais em sala de aula, sustentadas por aportes teóricos. A Teoria Eva Mitocondrial torna-se uma excelente opção para o docente subsidiar reflexões. 


\section{A teoria da Eva Mitocondrial}

A teoria da Eva Mitocondrial se caracteriza como uma opção para o trato com as questões etnicorraciais durante as aulas de Genética. Contrários a teorias como as de inferioridade africana, segundo as quais o negro é posto como inferior, como nos lembra Malavota (2011), alguns estudos científicos apontam a possibilidade de todos os indivíduos serem originários de um continente em comum, o africano. Entre esses estudos, a Secretaria Municipal de Educação de São Paulo afirma nas suas Orientações Curriculares (2008) ser a África o berço da humanidade e das civilizações, por ser o lugar das primeiras descobertas, invenções e instituições humanas.

A teoria da Eva Mitocondrial surgiu a partir de avaliações biológicas do material genético, DNA mitocondrial (mtDNA), presente em fósseis estudados em diferentes partes do globo. A teoria aponta o hominídeo como o ancestral em comum da espécie humana. A África é, portanto, palco dos processos interligados de hominização, desenvolvimento evolutivo do homem, e de sapienização, processo de construção de conhecimento e sabedoria (WEDDERBURN, 2005).

A teoria da Eva Mitocondrial ou Eva Africana defende ser a mulher africana a mãe de todos os seres humanos, a responsável pela origem de todos os indivíduos que evoluíram para a nossa espécie Homo sapiens. Por isso, essa mulher é colocada como "mãe africana". Para tal afirmação, a questão se baseia em dados genéticos (mtDNA) encontrados em registros fósseis (FOLEY, 2003).

Segundo Cavalli-Sforza (2002), o DNA mitocondrial analisado em pesquisas antropológicas e geológicas é conduzido às gerações seguintes pela herança citoplasmática da mulher, o que caracteriza uma relação de matrilinhagem. Por isso foi dado o nome de Eva mitocondrial à teoria. Dessa forma, é possível, por meio do material genético mitocondrial, investigar a evolução humana, pois sua integridade genética é facilmente mantida, a não ser em casos de mutações nos genes.

Grande parte do DNA humano localiza-se no núcleo celular, nos cromossomos. O DNA encontra-se na região extracelular; o citoplasma, especificamente, dentro das mitocôndrias, as quais são organelas importantes e possuem um DNA próprio, sendo capazes de realizar autorreplicação, além de serem responsáveis pela manutenção da vida do indivíduo através da produção de energia (ROBERTIS, 2003).

Com isso, essa teoria colabora para a mudança de paradigmas. As teorias que inferiorizam o negro reúnem forças contrárias para a igualdade entre diferentes etnias. Ao se apropriar do conhecimento científico, pautado na teoria em questão, é possível reunir forças positivas e contrárias ao preconceito, o qual é derivado do não questionamento de ideias vigentes. Com o auxílio de teorias questionadoras, que conduzem o alunado à criticidade, é 
possível contribuir para uma modificação no paradigma, assim o que era um preconceito fortemente enraizado passa, no mínimo, a não fazer mais sentido.

A teoria Eva Mitocondrial se caracteriza como uma opção ao professor para o trato com as questões etnicorraciais, e pode ser trabalhada fazendose uso de novas tecnologias, facilitadoras da aprendizagem. A Educomunicação, nesse caso, apresenta-se como uma proposta denotada de potencial.

\section{Educomunicação e o ensino da biologia}

O uso de novas tecnologias no ambiente escolar proporciona um aprendizado expressivo ao alunado. O discente tende a obter contato com a tecnologia desde a infância, sendo influenciado positivamente ou negativamente por ela no seu cotidiano (SANTOS, 2010). Além disso, cada vez mais a criança consegue desenvolver habilidades antes não apresentadas em sua faixa etária, isto devido ao fácil acesso à informação e à modernidade dos aparelhos eletrônicos.

A escola e o professor devem utilizar variados recursos para a melhor compreensão e fixação do conteúdo explanado em sala de aula. De acordo Pelizzare (2002), a aprendizagem torna-se significativa quando os alunos conseguem associar a nova informação estabelecida ao seu conhecimento prévio, sua experiência de vida. É nesse contexto que o estudante conseguiria aplicar seus conhecimentos em situações semelhantes ou variadas.

Uma das formas de trabalhar a diversidade de interesses entre professor e aluno é por meio da mídia-educação, também conhecida como Educomunicação, ou seja, uma proposta que abranja a fala, o quadro e outras tecnologias que chamam a atenção e despertam o interesse dos estudantes. Os professores, com isso, precisam aprender a trabalhar a mídia como fonte de aprendizado adicional (GAIA, 2001).

Quando falamos em Educomunicação, estamos nos referindo a um campo de pesquisa, de reflexão e de intervenção social, cujos objetivos, conteúdos e metodologias são essencialmente diferentes tanto da educação escolar quanto da Comunicação Social:

Investigar os fundamentos desse campo, discutir as inter-relações dos vários tipos de saberes que se fundem na Educação e na Comunicação constitui os principais objetivos teóricos desse novo campo. O que sentem e 
pensam as pessoas de si mesmas, dos outros e do mundo que as rodeia, não importando idade, sexo, credo ou condição social, por sua vez, são os conteúdos trabalhados na Educomunicação (SOARES, 2010).

A metodologia adotada na Educomunicação caracteriza-se não pelo interesse em respostas supostamente definidas para os problemas, mas pelo aguçamento das contradições. Assim, seja qual for o tipo ou a forma de conhecimento, o campo não somente tem condições de recebê-lo, mas, sobretudo, de promover o diálogo com ele e dele com os outros. A Educomunicação possibilita que se revelem e se tornem públicos os registros constantemente feitos, tanto pelos grupos organizados em torno da constituição dos saberes quanto de nós sobre nós próprios.

Segundo Sartori (2006), o processo comunicativo pode dispor-se no processo de mediação escolar a partir da Educomunicação, a qual propõe integrar práticas educativas com os sistemas de comunicação, além de criar e fortalecer ecossistemas comunicativos e melhorar o nível de expressão no ensino. Para Gaia (2001), essa prática tem por meta educar criticamente para a leitura dos meios tecnológicos e informacionais, e fazer com que professor e aluno alimentem o desejo de se manterem informados, de aprender permanentemente, de repassar e reproduzir conhecimento.

Nesse sentido, devido à mídia possuir a competência de influenciar diretamente no pensamento e atitude do indivíduo, se torna necessário fazer uso dela como uma forte aliada no aprendizado e trato com a diversidade. A desmitificação de estereótipos raciais, a partir de um apanhado biológico, pode ser capaz de destruir atitudes discriminatórias e visões pejorativas do negro, baseadas no fenótipo e na historicidade, marcada por teorias imagéticas, construídas para justificar a dominação da população negra.

\section{O locus: educomunicação e a realidade dos professores de biologia do IFPA campus Belém}

A Educomunicação pode ser entendida como um campo de atuação dotado de metodologia, caracterizada pelo aguçamento das contradições e não pelas respostas supostamente definidas (Silva, 2012), pode estar diretamen- 
te relacionada à desconstrução do preconceito e do racismo e ao ensino da Biologia, cuja área de abrangência se traduz em terreno fértil.

Nas entrevistas realizadas com os professores de Biologia do IFPA - Campus Belém, vimos que apesar de desconhecerem o termo "Educomunicação", todos eles realizam em sala de aula metodologias de ensino que denotam as características desse campo de atuação e acreditam que a Educomunicação pode estar diretamente relacionada ao ensino da Biologia.

Foram entrevistados três professores do sexo masculino e um do sexo feminino. Para efeito de melhor compreensão da realidade dos entrevistados, os gráficos a seguir revelam alguns dados referentes à formação inicial dos professores e à realidade com a qual se deparam diariamente em sala de aula. $O$ gráfico 1 mostra que muitos desses professores não tiveram contato com as abordagens etnicorraciais na graduação:

\section{Durante sua graduação, houve alguma ordagem relacionada ao preconceito racial?}

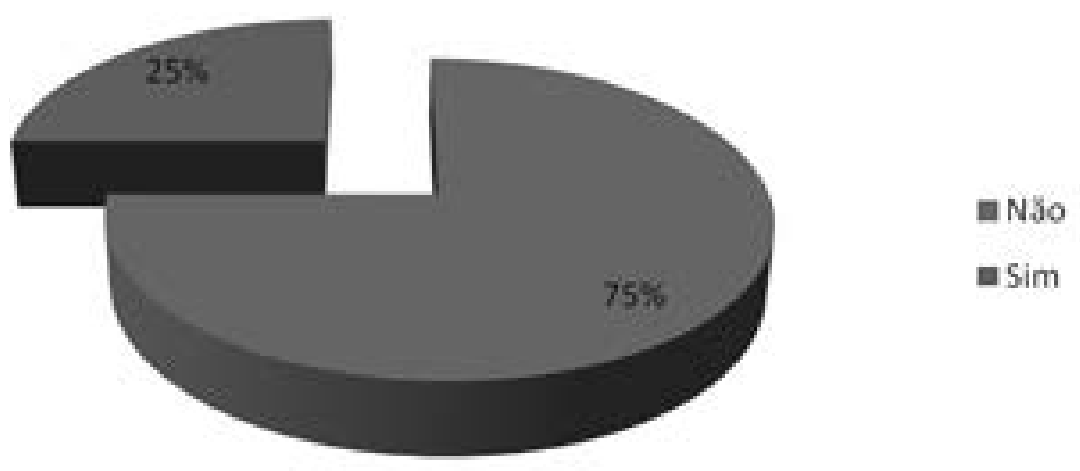

Gráfico o1: Porcentagem de professores que obtiveram, ou não, abordagens relacionadas ao preconceito racial durante suas respectivas graduações.

Isso reforça as inferências acerca do despreparo dos docentes para lidar com as questões etnicorraciais, provocadas pela deficiência na formação desses profissionais. O gráfico 2 revela que também na pós-graduação foi inexpressiva a presença de conteúdos relacionados às questões etnicorraciais. Apenas um dos entrevistados teve o contato com aportes teóricos dessa área: 


\section{Na pós-graduação foram trabalhados temas voltados ao preconceito racial $e$ à Teoria da Eva Mitocondrial?}
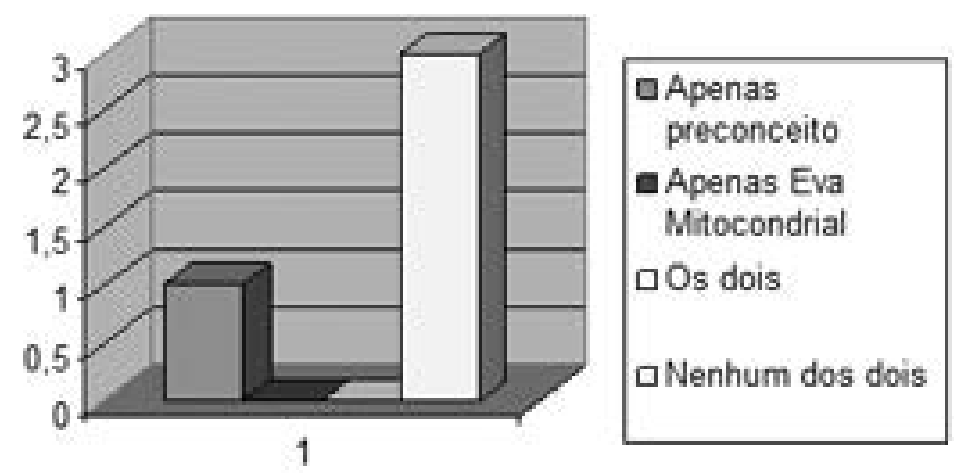

Gráfico o2: Porcentagem de professores que obtiveram, ou não, informações voltadas ao preconceito racial ou à teoria da Eva Mitocondrial em suas respectivas pós-graduações.

A partir desses dados é possível perceber a deficiência na formação dos docentes. Isso se caracteriza, em primeira instância, como um empecilho para que esse docente dissemine uma educação voltada para as relações etnicorraciais. O gráfico 3 irá mostrar que o conhecimento nessa área foi adquirido pelos professores posteriormente, durante os anos de atuação profissional no IFPA.

Detectamos, ainda, que apesar de $75 \%$ dos entrevistados ter declarado conhecer a teoria da Eva Mitocondrial, o conhecimento também não veio durante a formação desses professores (durante a graduação), mas por outros meios, como a experiência de atuação na especialização em Educação para Relações Etnicorraciais (ERER) dentro do IFPA, enquanto professor: 


\section{Durante a sua graduação, houve alguma abordagem relacionada à teoria da "Eva Mitocondrial"?}

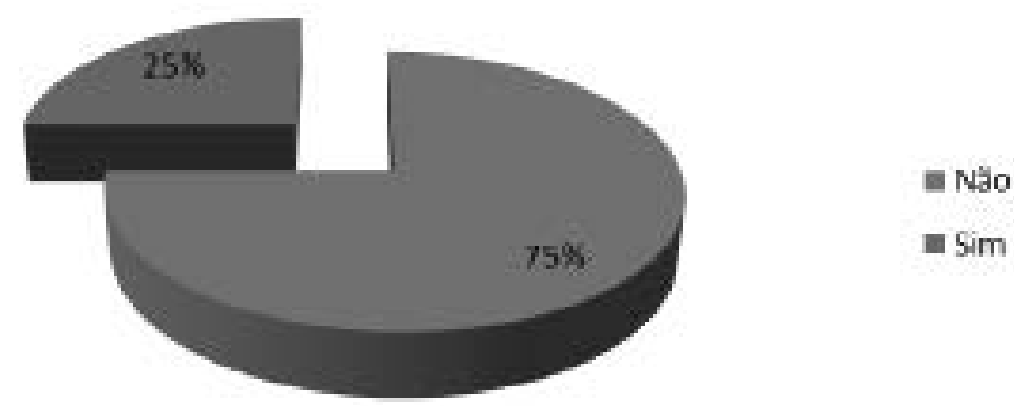

Gráfico o3: Porcentagem de professores que declararam conhecer a teoria da "Eva Mitocondrial” na graduação.

Percebemos no caso desses professores, que o conhecimento para o trato com a diferença deu-se por conta própria, como eles mesmos afirmam. Foi por meio de leituras, de pesquisas e da atuação como docente na Especialização em Educação para Relações Etnicorraciais no IFPA - Campus Belém.

Esse caso se assemelha à pedagogia do improviso, apontada por Coelho (2006), em que, pouco habituados ao longo da formação a relacionar as questões do Ensino e da Aprendizagem à área na qual são especialistas, os professores acabam por manifestar uma enorme dificuldade em utilizar o conteúdo curricular para o desenvolvimento das competências e habilidades recomendadas pelos parâmetros curriculares nacionais e pela legislação ultimamente publicada, com vistas ao trato da Diferença (Brasília, 2004).

Rocha (2011) explica que, livre da pedagogia do improviso, o docente deve dispor de instrumentos didáticos auxiliadores na educação, que tratem da invisibilização do negro. A Educomunicação é um campo repleto desses instrumentos e denotado de muitas possibilidades. Embora dizendo que não sabiam o que significava Educomunicação, percebemos que os quatro professores entrevistados aplicavam elementos dela em sala de aula.

A professora P1, por exemplo, diz, durante a entrevista, que costuma utilizar vídeos, filmes, trechos de desenhos animados, entre outros recursos em sala de aula. Ela afirma que isso facilita o aprendizado, concordando, dessa forma, com os pareceres de Pelizzare (2002), de que a escola e o professor devem utilizar variados recursos para a melhor compreensão e fixação do conteúdo explanado em sala de aula. A professora também diz que costuma abordar as temáticas racismo e preconceito durante suas aulas, "mas não em todos os conteúdos”. 
Trato em disciplinas como genética, onde é abordada a questão cromossômica, mostrando que não existe diferença genética, e que a diferença fenotípica não determina a diferença entre as pessoas. Os cromossomos de pessoas de etnias diferentes são iguais $(\mathrm{P} 1,2012)$.

P1 informa que conhece a teoria da Eva Mitocondrial, mas que não costuma utilizá-la no ensino médio. Ficou evidenciado que essa professora sabe conceituar a teoria, uma vez que, ao fazer parte de bancas de monografias, colaborando na especialização em Educação para Relações Etnicorraciais, do IFPA, por meio de publicações às quais teve acesso, e não na graduação nem na pós-graduação, tomou conhecimento da referida teoria.

A mesma pessoa informou que nunca lidou com situações de racismo e preconceito em sala de aula. O preconceito, na visão de $\mathrm{P} 1$, se caracteriza como uma divergência de comportamento e de pensamento. "As brincadeiras, por exemplos que se tira com os outros. Ai eu penso: será que essa pessoa realmente tem esse comportamento ou está só brincando?” (P1, 2012). Pelo gráfico 4, é possível visualizar a quantidade de professores que teve de intervir em situações de preconceito e racismo:

\section{Voce teve alguma experiencia com situaçōes de preconceito em sala de aula? Como se posicionou?}

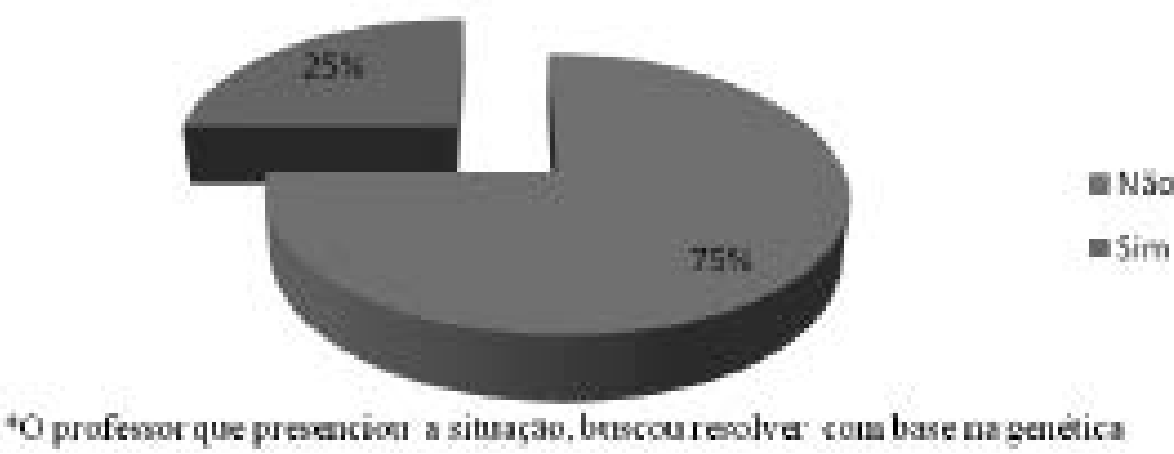

Gráfico o4: Porcentagem de professores que já teve de intervir em situações de preconceito e racismo em sala de aula e como reagiram a respeito. 
Como averiguado, 25\% dos entrevistados teve de lidar com as práticas discriminatórias citadas. Se esses profissionais contassem apenas com a formação inicial deles (graduação), observar-se-ia, nesse caso, um despreparo para lidar com as questões etnicorraciais.

No entanto, os quatro professores sabem reconhecer a importância da Biologia como disciplina desconstruidora de ideias pré-concebidas, aliada a recursos e práticas pedagógicas inovadores. Eles afirmam essa importância, mesmo tendo revelado que nunca tiveram contato com a disciplina Educação para Relações Etnicorraciais, durante a formação profissional. P2 justifica dizendo que "isso é atual, que é muito novo, e que atualmente os professores estão sendo preparados para iniciar o trabalho de disseminação desse conhecimento nas graduações”. Para P1:

O ensino da Biologia está estritamente relacionado justamente com essa parte da desconstrução da ideia de que existe diferença entre as pessoas e do conceito de raça. Não existem raças, existem etnias. E o conceito de etnia é um conceito mais cultural do que morfológico. A biologia vem justamente para mostrar a igualdade de cromossomos, mostrar que não se trata de diferença de raças, mostrar para os alunos que todos são iguais, inclusive os que têm deficiências. Somos da mesma constituição genética. A genética vem para comprovar essa igualdade entre as pessoas. Ai vai do professor saber repassar isso $(\mathrm{P} 1,2012)$.

Para P2:

O ensino da Biologia tem uma grande amplitude no que se refere à questão etnicorracial, principalmente nas disciplinas que envolvem evolução e genética. Tem muita informação para dar na questão de etnia. Até pela questão dos fósseis... Tem uma amplitude muito grande (P2, 2012).

Embora declarando que não sabe o que é Educomunicação, P2 também diz que utiliza em sala de aula como recursos didáticos o Datashow e músicas. Esse docente também revelou que tem utilizado muitos documentários em sala de aula e que o racismo é sempre abordado de forma interativa, "mas não dentro de um conceito amplo. É buscada uma forma mais simples de abordagem que coloque a proposta para o aluno de uma forma mais fácil" (P2, 2012). Sobre isso, Gadotti (2005) e Gohn (2006) dizem que o professor pode realizar um trabalho novo e em local diferente da sala de aula, caracterizando, assim, o espaço não formal como espaço de participação de atividades em grupo, independente de idade e até de áreas de estudo. Essas são premissas da Educomunicação. 
P2 conhece a teoria da Eva Mitocondrial e informa que a trabalhou em sala de aula, como parte do conteúdo da disciplina "Bases Biológicas para o Trato com ERER7". Diz que apesar de atuar há muito tempo como professor, nunca lidou com situações de preconceito e racismo. Na visão de $\mathrm{P} 2$, "preconceito é tudo aquilo que vai contra àquilo que faz a outra pessoa se sentir bem ou até se sentir discriminado perante outras pessoas. Ser discriminado é ser injuriado perante outras pessoas". Ou seja, aliando o conhecimento de $\mathrm{P} 2$ às propostas da Educomunicação temos um exemplo de educador voltado para as questões etnicorraciais.

P3 e P4 também não conhecem a Educomunicação, mas afirmam que costumam utilizar nas aulas data show, televisão, vídeos, filmes, entre outros recursos da comunicação. Ambos acham importante utilizar esses recursos. Para $\mathrm{P}_{4}$, isso "dá a conotação de união entre o passado e o presente, facilitando a discussão em sala”.

P3 diz que não costuma tratar de preconceito e racismo em sala de aula, mas que "mostra aos alunos que temos o mesmo material genético". P4 diz que aborda, mas ocasionalmente, a partir de alguns fatos que assiste na televisão.

P3 conhece a teoria da Eva Mitocondrial e sabe explicá-la, enquanto que $\mathrm{P}_{4}$ "já ouviu falar, mas não sabe descrevê-la”. P3 informa que nunca teve de intervir em situações de preconceito e racismo, mas que busca "esclarecer aos alunos acerca do genótipo e das Leis de Mendel8”. Já P4 teve de intervir em situações de preconceito, mas não de racismo. Segundo $\mathrm{P} 4$, teve de intervir diversas vezes em que alunos caçoavam do outro por obesidade e outras diferenças de padrão estético. "Ai eu tive que proporcionar situação de equilíbrio na sala de aula” ( $\mathrm{P} 4,2012)$.

$\mathrm{P}_{3}$ e P4 sabem conceituar preconceito e racismo: "Preconceito é um conceito dado de forma precipitada a alguém. O racismo é quando você 'qualifica' alguém pela cor da pele" $\left(\mathrm{P}_{3}, 2012\right)$. "Preconceito é tudo que estigmatiza o outro. Se você diz ao outro, por exemplo, 'tu não aprendes, porque tu és burro', é preconceito" (P4, 2012).

$\mathrm{P}_{3}$ e P4 também nunca tiveram contato com a disciplina Educação para Relações Etnicorraciais, durante a formação profissional. Para P3,

A Biologia pode contribuir com um conhecimento voltado para as questões etnicorraciais principalmente por meio da biologia molecular e dos conhecimentos sobre transcrição, tradução e expressão gênica, que mostram que o DNA é duplicado tendo uma mesma origem ( $\left.\mathrm{P}_{3}, 2012\right)$.

7 Educação para Relações Etnicorraciais.

${ }^{8}$ Conjunto de princípios relacionados à transmissão hereditária das características de um organismo a seus filhos. Consiste na base principal da genética clássica. Originou-se dos trabalhos de Mendel publicados em 1865 e 1866, os quais foram considerados controversos inicialmente, e redescobertos em 1900. 
Na opinião de $\mathrm{P}_{4}$, “a Biologia ajuda na medida em que o conhecimento é mostrado de forma diferenciada aos alunos e 'sai das paredes da universidade', indo até eles".

Concluindo as análises, no gráfico 5, percebemos que P1, P2, P3 e P4, apesar de não conhecerem a Educomunicação, utilizam meios que denotam algumas das suas características:

\section{Vocể utiliza recursos didáticos? Qual (is)?}

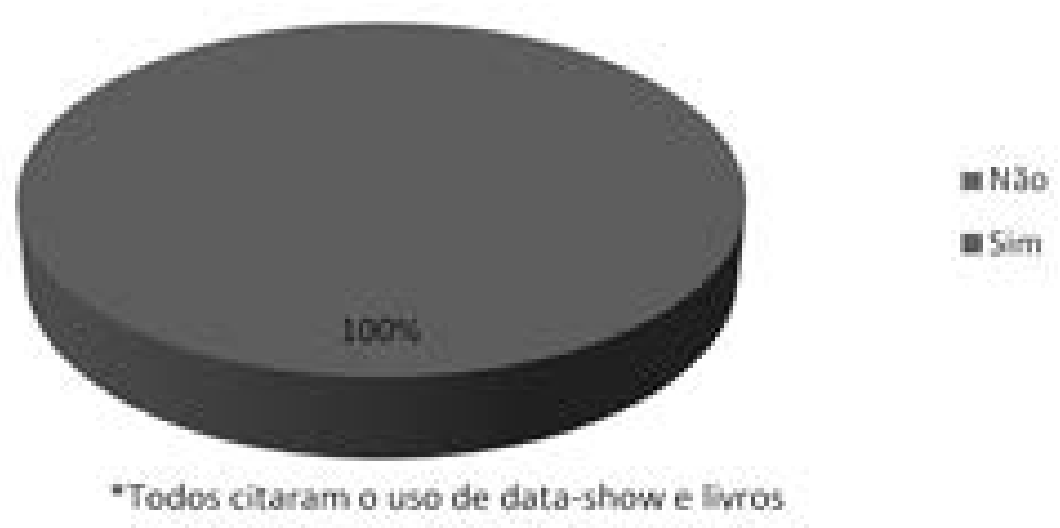

Gráfico o5: Porcentagem de professores que utilizam, ou não, recursos didáticos em suas aulas e quais recursos utilizam.

Observamos, inclusive, no gráfico 6, que é expressivo o número de professores que abordam as questões etnicorraciais em aula, munidos de um conhecimento nessa área, adquirido após o término da formação acadêmica, ou seja, ao longo dos anos de atuação profissional, haja vista que na graduação foi deficitário: 


\section{Você trabalha a questão etnicorracial nas suas aulas? De que forma?}

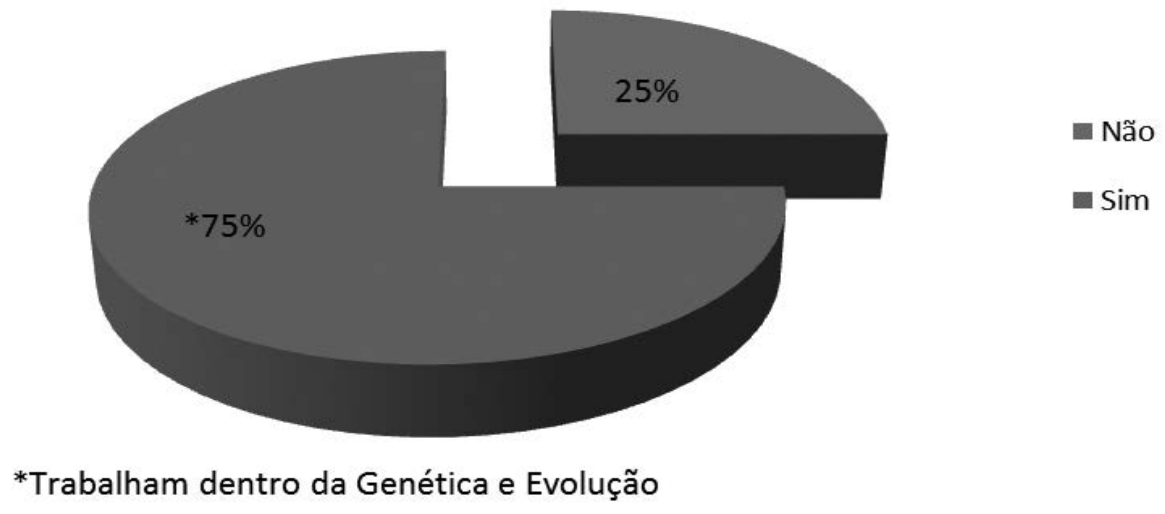

Gráfico o6: Porcentagem de professores que trabalham, ou não, a questão etnicorracial em suas aulas e de que forma abordam o tema.

Observamos que apesar de terem sido poucas as situações envolvendo preconceito e discriminação em sala de aula, em que os quatro professores entrevistados tiveram de intervir, essas situações existem e os professores devem estar preparados para lidar com elas. Sobre a realidade da precariedade da formação inicial desses docentes, também foi observada. Coelho (2006) diz que parte da responsabilidade pela reprodução de preconceitos e de práticas discriminatórias no universo escolar se deve a lacunas na formação docente. Segundo a autora, os cursos de formação de professores não preparariam os futuros profissionais para enfrentarem o processo educativo como uma totalidade, na qual a formação da identidade é etapa fundamental. E mais. Não encaminhavam procedimentos para a superação de vícios presentes na cultura brasileira hegemônica, na qual proliferam mecanismos de discriminação e práticas preconceituosas.

É perceptível, ainda, a relação das falas dos professores, de que são importantes as aulas interativas e apoiadas por recursos didáticos inovadores, com a seguinte afirmação de Pelizzare (2002): "a escola e o professor devem utilizar variados recursos para a melhor compreensão e fixação do conteúdo explanado em sala de aula". 


\section{Considerações Finais}

A ideia da construção da pesquisa surgiu durante a realização da Especialização em Educação para as relações Etnicorraciais (ERER), para tanto estabelecemos conexões entre a teoria Eva Mitocondrial, ensino e aprendizagem na disciplina de Biologia e reflexão crítica acerca do preconceito racial.

Por meio da apropriação do referencial teórico e da pesquisa de campo, foi possível perceber que, embora a maioria dos entrevistados não tivesse contato com a disciplina Educação para Relações Etnicorraciais na graduação e com as questões relacionadas à Teoria da Eva Mitocondrial, ao racismo e ao preconceito na graduação ou na pós-graduação, a Especialização em Educação para Relações Etnicorraciais tem sido um diferencial na trajetória acadêmica de muitos professores do IFPA-Campus Belém.

Nesse contexto, $75 \%$ desconhecia, durante a graduação, a teoria da Eva Mitocondrial. Dos entrevistados, $50 \%$ passou a conhecer a referida teoria por meio de pesquisas individuais e da necessidade em ministrar aulas para o curso de Especialização em Educação para Relações Etnicorraciais (ERER).

Foi possível compreender, ainda, que a especialização em ERER, no IFPA, e a inclusão no currículo da instituição da disciplina "Educação para Relações Etnicorraciais" influenciam significativamente no interesse e na necessidade dos profissionais da educação de conhecer mais a respeito da temática racial no Instituto, o que possibilitou o desenvolvimento de novos conhecimentos para docentes e discentes da pós-graduação.

Vimos que, apesar do conceito Educomunicação ser desconhecido pelos professores, eles utilizam recursos midiáticos e ferramentas tecnológicas que favorecem uma aprendizagem significativa, acreditando, dessa forma, no potencial dos aspectos da Educomunicação. Sem saber o que é Educomunicação os entrevistados concordam com a ideia de Pelizzare (2002), de que a aprendizagem torna-se significativa quando os alunos conseguem associar a nova informação estabelecida com o seu conhecimento prévio, sua experiência de vida. Concordando com Gaia (2001), eles veem a mídia como uma fonte de aprendizado adicional para o ensino da Biologia e procuram assegurar aulas interativas.

Ressaltamos, por fim, que a disciplina Biologia é colocada como fundamental para a desconstrução de estereótipos, sendo a genética uma das principais vertentes de esclarecimento, e a teoria da Eva Mitocondrial fundamental para a valorização dos povos e da cultura de origem africana e afrobrasileiras. Com base nisso, em parecer propositivo, apresentamos aos professores de Biologia do IFPA a disciplina como um campo repleto de possibilidades para o ensino crítico, desconstruidor do preconceito racial e sustentado por bases científicas. Aliada à concepção de ensino denomina- 
da Educomunicação, a Genética se torna aos professores do IFPA uma das principais vertentes de esclarecimentos.

\section{Referências Bibliográficas}

BORGES, R. M. R.; LIMA, V. M. R. Tendências Contemporâneas do Ensino de Biologia no Brasil. Revista Electrónica de Enseñanza de las Ciencias, Vol. 6, $\mathrm{N}^{0} 1,2007$.

BRASIL. Parâmetros curriculares nacionais. Brasília: Ministério da Educação, 1998.

Plano Nacional de Implementação das diretrizes Curriculares Nacionais para o ensino de História e Cultura Afrobrasileira e Africana. Brasília: MEC/SECAD, 2003. Disponível em: < http:// www.ifrj.edu.br/webfm_send/271> Acesso em: 24 de jun. de 2012.

Educação anti-racista: caminhos abertos pela Lei Federal $\mathbf{n}^{\circ}$ 10.639/2003. Brasília: Ministério da Educação, Secretaria de Educação Continuada, Alfabetização e diversidade, 2005.

- Programa ética e cidadania: Relações étnicorraciais e de gênero. Brasília: Ministério da Educação, 2007.

CASTOLDI, R.; POLINARSKI, C. A utilização de recursos didático-pedagógicos na motivação da aprendizagem. I Simpósio Nacional de Ensino de Ciência e Tecnologia. 2009.

CAVALLEIRO, E. (org.). "Educação anti-racista: compromisso indispensável para um mundo melhor”. São Paulo: Summus, 2001.

CAVAlli-SFORZA, L. ; CAVALLI-SFORZA, F. Quem Somos Nós?- História da Diversidade Humana. São Paulo: Editora UNESP, 2002.

CHAGAS, L. C. Racismo, preconceito e trajetória escolar de crianças negras e brancas: a realidade de Sergipe. IV Colóquio Internacional "educação e contemporaneidade". Laranjeiras-SE, 2010. 
COELHO, W. N. B.; COELHO, M. C. (orgs.). Raça, cor e diferença. Belo Horizonte: Mazza, 2008.

COELHO, Wilma de Nazaré Baia. A cor ausente: um estudo sobre a presença do negro na formação de professores no Estado do Pará, 1970-1989. Belo Horizonte, Mazza, Belém, UNAMA, 2006.

DESCONHECIDO. Recursos didáticos. Disponível em: $<$ http://www. uemmg.org.br/list.noticia.php/origem/20/noticia/511/titulo/Recursos_ didaticos > Acessado em 10 jan 2012.

FOLEY, R.; ZIMBRES, P. (trad.). Os humanos antes da humanidade: Uma perspectiva evolucionista. São Paulo: Editora UNESP, 2003.

FRACALANZA, D. C.; FRACALANZA, H. O ensino de Biologia: da análise de suas características à elaboração de propostas alternativas. In: FRACALANZA, H. (Coord.). Cadernos de Ensino de Biologia (1). Campinas: Faculdade de Educação, Universidade Estadual de Campinas, 1985.

GAIA, R. Educomunicação \& mídias. Maceió: Edufal, 2001.

GERZSON, V. R. S. A mídia como dispositivo da governamentabilidade neoliberal: os discursos sobre educação nas revistas Veja, Época e Istoé, 2007. Disponível em: <http://www.ufrgs.br/neccso/pdf/ tese_midiacomodispositivo.pdf> Acesso em: 01 set. 2011.

HERSCHMANN, M.; PEREIRA, C. A. M. Mídia, memória e celebridades: estratégias narrativas em contextos de alta visibilidade. Rio de Janeiro: E-Papers Serviços Editoriais, 2005. $2^{\text {a }}$ edição p. 226.

KRASILCHIK, M. Prática de Ensino de Biologia. São Paulo: Universidade de São Paulo, $4^{\text {a }}$ ed. 2004.

LIBÂNEO, J. C. Democratização da escola pública: a pedagogia crítico-social dos conteúdos. $19^{\circ}$ ed. São Paulo: Loyola, 2005.

MAGNOLI, D. Uma gota de sangue: História do pensamento Racial. São Paulo: Contexto, 2009.

MAIA, P. D.; MONTEIRO, I. B.; MENEZES, A. P. S. Diferenciando a aprendizagem da biologia no ensino médio, através de recursos tecnológicos. Anais 
do $1^{\circ}$ Seminário Nacional de Educação Profissional e Tecnológica. Belo Horizonte, MG: CEFET - MG, 2008. Disponível em: <http://www. senept.cefetmg.br/galerias/Arquivos_senept/anais/terca_tema5/TerxaTema5Poster4.pdf $>$. Acesso em: 16 nov. 2012.

MALAVOTA, C. M. A Invenção da África: Introdução aos Estudos Africanos em Diáspora. Disponível em:< http://www.moodle.udesc.br/course/ view.php> Acesso em: 16 nov. 2012.

MENEZES, W. O preconceito racial e suas repercussões na instituição escola. 2002. Disponível em:< http://www.fundaj.gov.br/tpd/147. html> Acesso em: 18 jan. 2012.

PENA, F. Teoria do Jornalismo. $2^{\mathrm{a}}$ Edição, $2^{\mathrm{a}}$ reimpressão. São Paulo: Contexto, 2008.

PELIZZARE, A.; KRIEGL, M. DE L.; BARON, M. P.; FINCK, N. T. L.; DOROCINSK, S. I. Teoria da Aprendizagem significativa segundo Ausubel. Revista PEC, Curitiba, v.2, n.1, p.37-42, jul. 2001-jul. 2002.

ROBERTIS (Jr.), H. P. DE. Biologia Celular Molecular. Guanabara-Koogan: RJ, 2003.

SALES, A. B.; OLIVEIRA, M. R.; LANDIM, M. F. Tendências atuais da pesquisa em Ensino em Biologia: Uma análise preliminar de periódicos nacionais. In V Colóquio Internacional "Educação e Contemporaneidade". Anais eletrônicos. ISSN 1982-3657. São Cristovão- SE, 2011. Disponível em: $<$ http://www.sigaa.ufs.br>. Acesso em: 10 nov. 2012.

SANT'ANA, M. T. DE. A importância de aulas práticas e o uso de recursos tecnológicos nas aulas de ciências biológicas. Monografia (Especialização) - Universidade Gama Filho, Brasília, 2010.

SANT'ANA, A. O. História e conceitos básicos sobre racismo e seus derivados. IN: MUNANGA, K. (Org.). Superando o racismo na Escola.

SANTOS, P. C. A utilização de recursos audiovisuais no ensino de Ciências: tendências entre 1997 e 2007. 2010. 179. Dissertação (Mestrado)- faculdade de Educação, Universidade de São Paulo (USP), São Paulo, 2010 .

SANTOS, S. A. (org.). Ações afirmativas e combate ao racismo nas Américas. Brasília: Ministério da educação, Secretaria de Educação Continuada, Alfabetização e diversidade, 2005. 
SARTORI, A. S. Inter-relações entre comunicação e educação: a educação e a gestão dos fluxos comunicacionais na educação a distância. UNIrevista - Vol. 1, 2006.

SCHRAMM, M. L. K. As tendências pedagógicas e o ensino-aprendizagem da arte. In: PILLOTTO, S. S. D.; SCHRAMM, M. L. K. (Org.). Reflexões sobre o ensino das artes. Joinville: Ed. Univille, 2001.

SECRETARIA MUNICIPAL DE EDUCAÇÃO. Diretoria de Orientação Técnica. Orientações Curriculares: expectativas de aprendizagem para a educação étnico-racial na educação infantil, ensino fundamental e médio / Secretaria Municipal de Educação - São Paulo: SME / DOT, 2008; P. 41-60.

SEVERINO, A. J. Metodologia do Trabalho Científico. São Paulo: Cortez, 2007.

SILVA, A. C. Desconstruindo a discriminação do negro no livro didático. EDUFBA, 2001.

SILVA, D. B. As Principais Tendências Pedagógicas na Prática Escolar Brasileira e Seus Pressupostos de Aprendizagem. Disponível em: <http://www.ufsm.br/lec/o1_oo/DelcioL\&C3.htm> Acessado em 24 nov. 2012.

SILVA, P. B. Espaços para a Educação das Relações Interétnicas: Contribuições da Produção Científica e da Produção Docente, entre Gaúchos, sobre Negro e Educação. In: SILVA, L. H. (org.) A Escola Cidadã no Contexto da Globalização. Petrópolis, Vozes, 1998.

SOARES, D. Educomunicação - O que é isto? Instituto de Educação e Cultura: 2010

SOUZA, S. E. O uso de recursos didáticos no ensino escolar. In: I Encontro de Pesquisa em Educação, IV Jornada de Prática de Ensino, XIII Semana de Pedagogia da UEM: "Infância e Práticas Educativas". Arq Mudi. 2007.

TEIXEIRA, P. M. M. Pesquisa em ensino de biologia no Brasil [19722004]: um estudo baseado em dissertações e teses. Tese (Doutorado) - Faculdade de Educação, Universidade Estadual de Campinas. Campinas, SP: [s. n.], 2008.

VEIGA, I. Didática: Uma retrospectiva histórica. In: VEIGA, I. (Ed.). Repensando a Didática. Campinas: Papirus, 1978. 
WEDDERBURN, Carlos Moore. Novas Bases para o Ensino de História da África no Brasil. In: MEC/BID/UNESCO. Educação Anti-Racista: caminhos aberto pela Lei Federal n. 10.639/2003. Brasília: MEC/SECAD, 2005. 